\title{
Poverty reduction during 1990-2013: did millennium development goals adoption and state capacity matter?
}

Article

Published Version

Creative Commons: Attribution 4.0 (CC-BY)

Open Access

Asadullah, M. N. and Savoia, A. (2018) Poverty reduction during 1990-2013: did millennium development goals adoption and state capacity matter? World Development, 105. pp. 7082. ISSN 0305-750X doi:

https://doi.org/10.1016/j.worlddev.2017.12.010 Available at https://centaur.reading.ac.uk/79735/

It is advisable to refer to the publisher's version if you intend to cite from the work. See Guidance on citing.

To link to this article DOI: http://dx.doi.org/10.1016/j.worlddev.2017.12.010

Publisher: Elsevier

All outputs in CentAUR are protected by Intellectual Property Rights law, including copyright law. Copyright and IPR is retained by the creators or other copyright holders. Terms and conditions for use of this material are defined in the End User Agreement.

www.reading.ac.uk/centaur 
Central Archive at the University of Reading

Reading's research outputs online 


\title{
Poverty reduction during 1990-2013: Did millennium development goals adoption and state capacity matter?
}

\author{
M. Niaz Asadullah ${ }^{\mathrm{a}, \mathrm{b}, \mathrm{c}, \mathrm{d}, \mathrm{e}}$, Antonio Savoia ${ }^{\mathrm{f}, *}$ \\ ${ }^{a}$ Faculty of Economics and Administration, University of Malaya, Malaysia \\ ${ }^{\mathrm{b}}$ School of Economics, University of Reading, UK \\ ${ }^{\mathrm{c}}$ Centre on Skills, Knowledge and Organisational Performance (SKOPE), Oxford, UK \\ ${ }^{\mathrm{d}}$ IZA, University of Bonn, Germany \\ ${ }^{\mathrm{e}}$ Global Development Institute, University of Manchester, UK \\ ${ }^{\mathrm{f}}$ Effective States and Inclusive Development Centre and Global Development Institute, University of Manchester, Oxford Road, Manchester M13 9PL UK
}

\section{A R T I C L E I N F O}

\section{Article history:}

Accepted 11 December 2017

\section{Keywords:}

SDGs

Poverty

Governance

Institutions

State capacity

Convergence

\begin{abstract}
A B S T R A C T
While poverty reduction remains central in the Post-2015 Agenda, its determinants remain debated in the literature, especially the role of structural conditions related to governance. This paper provides an assessment of two key dimensions: the global adoption of MDGs and state capacity. We do so by studying whether they facilitated convergence in income poverty measures, using cross-section and panel methods, with data on 89 developing economies for the period 1990-2013. We find that poverty headcount and gap measures tended to decrease faster in countries with initially higher income poverty. Such convergence accelerated after 2000, suggesting that MDGs adoption was instrumental to poverty reduction. However, this still leaves unexplained substantial variation in poverty reduction performance across countries. Such variation is explained by state capacity: countries with greater ability to administer their territories in 1990 experienced faster income poverty reduction and were more likely to have achieved the MDG target. This result is insensitive to robust regression methods and to a large set of controls (initial level of income, dependence on natural resources, education and health inputs, dependence on foreign aid, ethnic fractionalization, regional effects and a set of governance variables). As good governance and effective institutions are included in the Sustainable Development Goals, this result provides empirical justification for this move, suggesting that more effective states could be crucial to sustain the development progress achieved so far.
\end{abstract}

(c) 2017 Elsevier Ltd. All rights reserved.

\section{Introduction}

As the Millennium Development Goals (MDGs) period has just ended, this is the time to assess successes and failures, trying to learn lessons to inform the next set of global development goals and policies. Between 1990 and 2015, as many as 1 billion people have been lifted out of poverty around the world (UNDESA, 2015). However, the determinants of achieving the MDG goal of halving poverty remain debated in the literature, especially the role of structural factors related to governance conditions. In particular, it is not clear which governance dimensions matter and the evidence on their significance remains mixed (Dalgaard \& Erickson, 2009; Fiszbein, Kanbur, \& Yemtsov, 2014; Kwon \& Kim, 2014; Smith \& Haddad, 2015; Sumner \& Tiwari, 2009). In the last two

\footnotetext{
* Corresponding author.

E-mail address: antonio.savoia@manchester.ac.uk (A. Savoia).
}

decades, much poverty has been reduced, even in countries like Uganda and Bangladesh, which ranked poorly in a wide range of governance quality indicators, challenging the view that there may be no ultimate "governance trap" (Asadullah, Savoia, \& Wahiduddin, 2014; Mahmud, Asadullah, \& Savoia, 2013; McGee, 2000). Nonetheless, key policy reports and development agencies routinely emphasize improved governance as a key pathway to achieving the MDG goals by 2015 (e.g. see United Nations Millennium Project, 2005). At the same time, the global adoption of MDG targets per se, which is an element of global governance, is likely to have mobilized political consensus around the agenda of poverty reduction and provided a focus for policy advocacy (Fukuda-Parr, 2011; Fukuda-Parr \& Hulme, 2011; Hulme, 2015; Waage et al., 2010). ${ }^{1}$

\footnotetext{
${ }^{1}$ However, for an opposite argument (i.e., that MDGs adoption may demoralize governments in regions where poverty is very high), see Easterly (2009).
} 
Our paper seeks to contribute to this debate by undertaking a systematic re-assessment of the income poverty eradication achievements, looking at the role of two key governance dimensions. One is the role of changes in development policy at the global level, i.e., assessing to what extent the adoption of the MDGs had an impact. The second is at the national level: assessing the role of state capacity, which is an under-researched aspect in the recent debate (Savoia \& Sen, 2015). The two are related, such that it is appropriate to analyze them concurrently, because the effects of changes in global governance may or may not be reflected in individual countries' poverty eradication policies and policy implementation, depending on the underlying governance conditions at national level. This exercise is worthwhile, because income poverty continues to be a key development goal in the Post-2015 Agenda and because it improves our understanding of the structural conditions that facilitated its eradication.

Apart from the development goals literature, such an assessment contributes to the broader research agenda on good governance (Grindle, 2004), now seen as both intrinsically and instrumentally valuable to development progress (Hulme, Savoia, \& Sen, 2015). It is instrumental to development, as academics seem to agree that improving the design of rules and regulations, the effectiveness of policies and the competence of public bodies is key to improving economic development (e.g., Baland, Moene, \& Robinson, 2010). In the last two decades, research has been striving to assess the effect of economic institutions on national income levels or growth rates (e.g., Acemoglu, Johnson, \& Robinson, 2001). Recent arguments emphasize the role of state capacity (Besley \& Persson, 2011; Fukuyama, 2013). Much of this research focuses on the effects on economic development (e.g., Dincecco \& Prado, 2013), but other development outcomes, such as poverty and inequality, have received far less attention (Savoia \& Sen, 2015). ${ }^{2}$ By focusing on poverty reduction, our paper also contributes towards filling this gap. Also, existing research has often conflated state capacity with state performance (Centeno, Kohli, \& Yashar, 2017). It is important to distinguish between the two: the former is about institutions and the latter is about outcomes. Our paper tries to do that too, by considering the separate effects of administrative and legal capacity on poverty reduction. Governance is also intrinsically valuable, because it is a development goal in itself in the Post2015 development framework, as Goal 16 of the Sustainable Development Goals (SDGs). Therefore, understanding the role of governance deficits, and state capacity in particular, for income poverty eradication may shed light on whether and how this choice could support development progress in other SDGs areas.

An empirical analysis of income poverty eradication requires examining whether (and how fast) differences in income poverty levels among countries are narrowing. But should we expect them to narrow? There are both "endogenous" and "exogenous" mechanisms supporting the hypothesis of convergence in poverty levels. Important exogenous mechanisms have to do with the influence of former colonial powers through development cooperation and the pressure from the international community through mechanisms of global governance, such as the adoption of MDGs. Being comparative, performance indicators like MDGs can influence state policy outputs, as they facilitate the monitoring of state behavior and

\footnotetext{
${ }^{2}$ An important exception is Cingolani, Thomsson, and de Crombrugghe (2015), showing that states with greater administrative capacity reduce child mortality and tuberculosis prevalence. Imai, Gaiha, and Thapa (2010), and Tebaldi and Mohan (2010), also offer evidence that upholding the rule of law and controlling corruption reduce poverty levels. See also Cook (2006) for an early discussion pointing to the importance of state effectiveness for achieving pro-poor growth and progress towards the MDGs target of poverty reduction in East Asia. For evidence against the hypothesis that good governance leads to poverty reduction, see Kwon and Kim (2014), which finds that good governance only contributes to poverty reduction in middle-income countries, not low-income ones.
}

serve as a tool for international governance (Kelley \& Simmons, 2015). ${ }^{3}$ Adoption of MDGs is also likely to have improved the targeting and flow of official development assistance (ODA), ensuring that aid emphasizes human development and/or is disproportionately allocated to countries that need to make the most progress on the MDGs (Addison, Niño-Zarazúa, \& Tarp, 2015). Moreover, MDGs adoption has influenced national development plans, leading to the introduction of Poverty Reduction Strategy Papers (see Seyedsayamdost, 2017). Early assessments have shown that these are, on balance, important means for making progress on MDGs (see Booth, 2003) and recent econometric evidence found that the effect of ensuing policies has led to greater reductions in headcount poverty and infant mortality (Elkins, Feeny, \& Prentice, 2017). We would thus expect that poverty convergence could have started or accelerated with adoption of the MDGs and the ensuing renewed effort to tackle poverty.

Regarding endogenous mechanisms, one should expect poverty rates to converge across countries, since mean household incomes across countries tend to converge and since growth in mean incomes reduces the absolute incidence of income poverty (Ravallion, 2012). ${ }^{4}$ Other mechanisms of poverty convergence could derive from diminishing returns to antipoverty policy and how and whether actors within the economy choose to tackle poverty. In analogy with capital accumulation and income convergence, the concept of diminishing returns could also be applicable to poverty reduction, as the early 'units' of antipoverty measures are relatively more effective and less costly to attain. It could be much less difficult and costly to attain a lower level of poverty from an initially high level than from a low level (see Noorbakhsh, 2007). For example, in an economy with a high number of poor, it would be relatively easy to target and reach recipients, and it should be easier to build political support in face of widespread poverty. On the contrary, antipoverty policy implementation could be more difficult if an economy already has relatively low levels of poverty, as it could be politically more difficult to prioritize poverty reduction interventions. Poverty reduction could also be costly if the remaining poverty is entrenched and in the form of traps. Regardless of which of the above endogenous mechanisms is at work, we hypothesize that countries' capacity for poverty reduction, and hence eventual convergence in poverty levels, is subject to structural governance conditions concerning the institutional capability of states to deliver policies benefiting their citizenry, i.e., state capacity. Therefore, poverty convergence may be more pronounced in countries with greater state capacity. We suggest that this effect could work through two channels: through higher administrative ability when delivering poverty-reducing policies (Bardhan, 2005, 2016; Bockstette, Chanda, \& Putterman, 2002; Evans \& Rauch, 1999) and through

\footnotetext{
${ }^{3}$ Kelley and Simmons (2015) argue that, once rulers realize that they are being monitored, they may change their priorities to meet external expectations. They discuss three mechanisms through which indicators can affect policy outcomes: (a) they help to attract or retain domestic political support and hence influence national policy making; (b) performance indicators can work through direct peer shaming; (c) indicators may impact policy by activating transnational social pressure.

${ }^{4}$ Poverty convergence is defined in proportionate, rather than absolute, terms in Ravallion (2012). The presence of poverty convergence by the proportionate definition implies that poorer countries tend to see larger relative reductions in their poverty rate. Countries starting out with a high incidence of absolute poverty should enjoy a higher subsequent growth rate in mean consumption and (hence) a higher proportionate rate of poverty reduction. Using a sample of household income data that covers about 90 developing countries between 1977 and 2007 and focusing on the conventional poverty headcount ratio at \$2/day, Ravallion (2012) does not find evidence of convergence in poverty headcount ratios across countries. Cuaresma, Klasen, and Wacker (2016), however, reexamine this hypothesis, arguing for a specification based on absolute convergence and finding robust evidence of convergence in absolute poverty headcount ratios and poverty gap measures. Furthermore, Cuaresma, Klasen, and Wacker (2017), re-investigating Ravallion (2012), find that the apparent absence of proportionate convergence was sensitive to including a group of influential observations from the transition economies.
} 
greater ability to provide legal infrastructures conducive to economic growth (Besley \& Persson, 2011).

Whether MDGs adoption and state capacity have affected the ability of economies with higher poverty levels to catch up with economies with lower poverty levels (and how fast) is ultimately an empirical matter. This paper lets the data speak for themselves, providing a set of stylized facts as a base for future research. We present results based on the notion of $\beta$-convergence, using a range of international income poverty measures, part of the set of the official poverty eradication indicators, with a sample ranging from 60 to 89 developing economies for the period 1990-2013. We find that differences across countries have narrowed: both poverty headcount and poverty gap measures tended to decrease faster in countries with initially higher income poverty, regardless of their non-poverty initial conditions, such as the initial level of income, dependence on natural resources, dependence on foreign aid, and ethnic fractionalization. However, the variation in the speed of convergence seems to depend on whether economies shared the same structural characteristics in terms of governance conditions. Supporting our hypothesis, the evidence suggests that the lack in the convergence process of any significant acceleration after the adoption of the MDGs reflects the variation between countries of national-level governance quality. In particular, we show that for a number of developing countries, such as Nigeria, Lesotho, Madagascar, and Zambia, the failure to achieve the 2015 MDG target of halving poverty is significantly explained by the challenge posed by poor state capacity: countries that suffered from deficits in the ability to administer their territories in 1990 were less likely to have achieved the MDG target on poverty reduction by 2013.

Apart from contributing to the literature on global development goals, this paper adds to a separate literature that has long been interested in the idea of convergence. Traditionally, empirical work has been concerned with convergence in national income levels (e.g., Barro, 2015; Pritchett, 1997; Quah, 1993; Rodrik, 2013; Sala-i-Martin, 1996). But recent analysis of convergence has also extended to the evolution of other development outcomes, such as health and education variables. ${ }^{5}$ However, the role of structural factors facilitating or hindering convergence has not received sufficient scrutiny, although it is an important aspect in determining whether contemporary differences in development outcomes across countries are transitory or permanent. This paper contributes towards filling this gap with respect to income poverty eradication, by focusing on governance conditions.

The paper proceeds as follows. Section 2 describes the data and provides some descriptive statistics on the evolution of income poverty across countries. Section 3 presents the econometric evidence on whether differences in poverty levels across countries are narrowing, while Sections 4 and 5 extend the analysis to the role of state capacity and MDGs adoption. Section 6 concludes.

\footnotetext{
5 Some empirical analysis looked at a broad range of standard of living variables covering up to four aspects: health, education, rights and infrastructure - and found that these measures are generally converging (Kenny, 2005; Neumayer, 2003), although this is (perhaps unsurprisingly) not the case when such variables are measured using an achievement index (Hobijn \& Franses, 2001). Other work concentrated on specific variables. For example, Deaton (2004) and Canning (2012) looked at the evolution of health, showing convergence in life expectancy across countries. Noorbakhsh (2007) extended the concept of convergence to human development, finding evidence of weak absolute convergence over the period 19752002. However, findings from a long-run perspective seem to point to a partial catching up between the OECD countries and the rest taking place in the 1913-1970 period, with an overall widening of the human development gap since 1870 (Prados de la Escosura, 2015). Closer to the focus of this paper, Ortega, Casquero, and Sanjuán (2016) showed that the countries' capacity for convergence in human development is subject to the level of corruption, and that convergence is more pronounced in countries with lower levels of corruption.
}

\section{Data}

This section introduces the key variables. It also offers crossnational poverty eradication statistics, comparing countries at different stages of economic development.

\subsection{Poverty eradication measures}

We use four core international poverty measures, as provided by the World Bank (2015), with a sample ranging from 60 to 89 developing and emerging economies and the longest period of analysis being 1990-2013. They are the poverty headcount and poverty gap, both at $1.25 \$$ and $2 \$$ a day. The country list is the Appendix.

\subsection{Trends in poverty eradication}

Table 1 reports descriptive statistics for the difference between initial and final poverty measures, and for their initial levels. On average, there has been a reduction in poverty levels across all four measures. However, the progress in poverty eradication, in terms of both headcount and gap measures, has not been uniform. It seems to increase as one moves from economies at a higher stage of economic development to those at lower stages. Since the 1990s, low-income economies have experienced the largest poverty reductions by the end of the observed period. In a significant number of cases, the magnitude in poverty reduction is such as to indicate significant progress towards achieving MDG Goal 1. An important exception is the case of the poverty headcount ratio at $\$ 1.25$ a day in low-income economies, which seems not to have decreased fast enough to half its initial level.

A second stylized fact is that the larger poverty reductions in countries at lower stages of development, which are those showing higher initial poverty, are allowing them to catch up with higher income economies. This is suggestive of a process of equalization in poverty levels across countries over time, which we investigate further in the next section by offering econometric testing. ${ }^{6}$

\section{Are differences in poverty levels among countries narrowing?}

Having presented the data and stylized facts on the evolution of poverty, this section provides econometric evidence on the existence and significance of poverty eradication. We proceed in two stages. We begin by discussing the methodology. Then we present the results from a range of convergence tests.

\subsection{Methodology}

We need methods allowing us to obtain evidence on progress in poverty eradication and an appreciation of its speed, and to assess whether structural conditions matter in this process. This requires testing for $\beta$-convergence (as known in the literature on economic growth): an approach capturing whether countries with higher initial poverty experience larger poverty reduction than less povertyridden countries, and so tend to "catch up", under different initial conditions. ${ }^{7}$ The corresponding test, in its simplest form, is a regres-

\footnotetext{
${ }^{6}$ In Table 1 , sample sizes between the change in poverty measures and their initial level vary. But this does not affect the comparisons or change the above description. Results obtained by comparing the same sample for both changes and initial levels (not reported here, but available upon request) show little sensitivity.

7 Others have emphasized a different statistical notion of convergence (e.g., Quah, 1993): $\sigma$-convergence, which looks at whether the cross-sectional dispersion across countries is decreasing, and for which $\beta$-convergence is a necessary, but not sufficient condition (see Sala-i-Martin, 1996). We do not pursue this approach, because it would not allow us to focus on whether initial conditions matter for poverty convergence and on estimating its speed, while both are interesting to assess the progress on poverty eradication.
} 
Table 1

Poverty trends: 1990-2013.

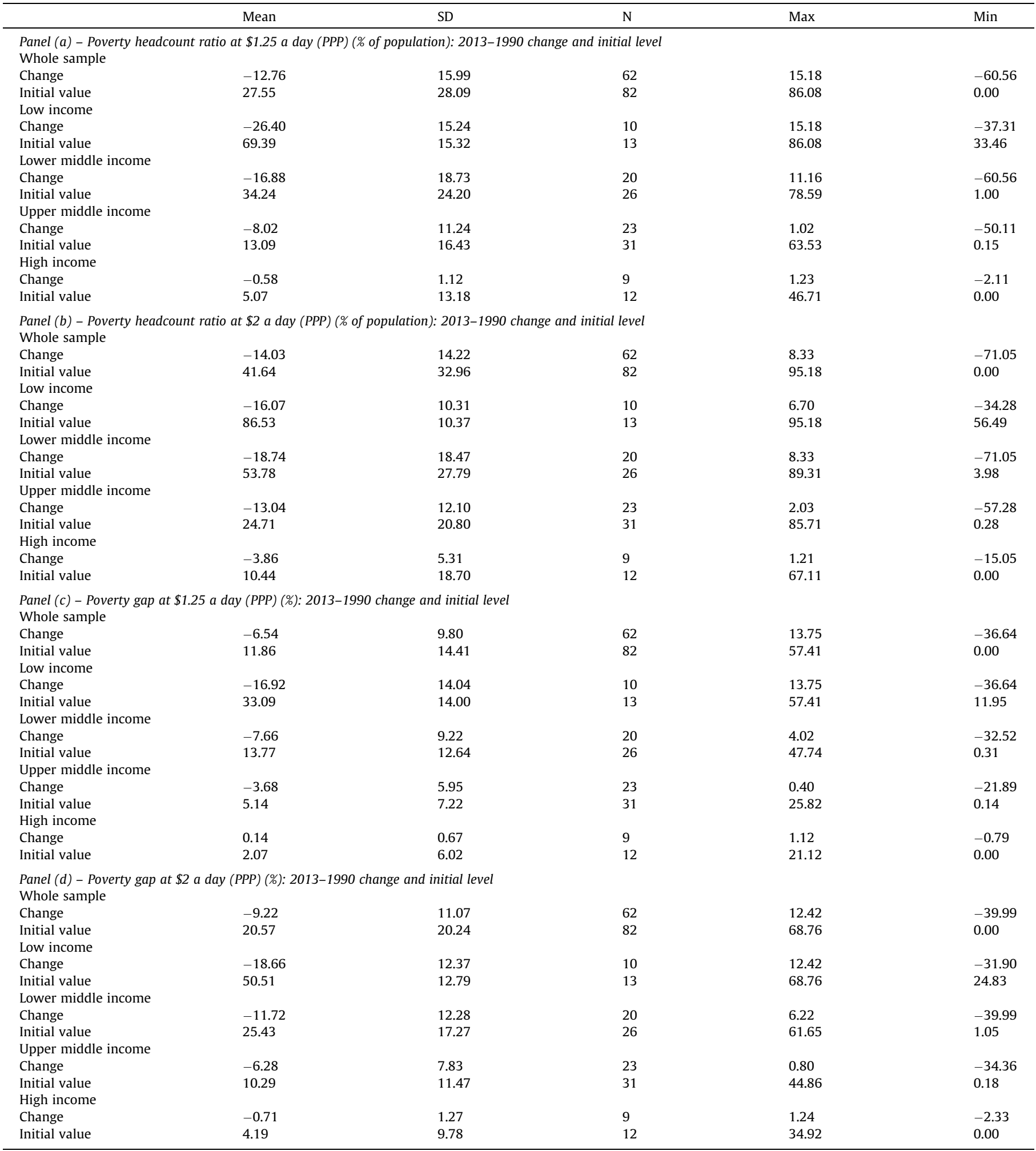

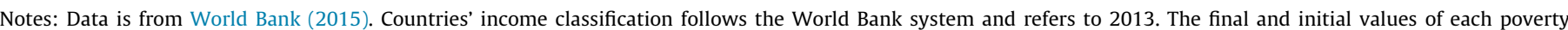
measure are taken at 2013 and 1990 circa, to obtain the largest number of observations.

sion (based on cross-section data) of the observed absolute changes over time on a given poverty measure on the measure's initial values across countries. Let $\Delta P_{i t}$ denote the difference in poverty index (any measure) in country $i$ observed at both date $t=0$ and $t=D$. A test equation for convergence is then:
$\Delta P_{i t}=\alpha+\beta P_{i 0}+\varepsilon_{i}$ with $i=1, \ldots, N$

where $\alpha$ and $\beta$ are parameters to be estimated and $\varepsilon_{i}$ is a zero mean error term. Eq. (1) tests whether economies with higher poverty levels tend to experience larger absolute reductions in their poverty 
rates and so catch up with economies with lower poverty levels. ${ }^{8} \mathrm{~A}$ negative (positive) estimate of the parameter $\beta$ implies that there is poverty convergence (divergence) and its magnitude expresses the speed of convergence (divergence). In particular, Eq. (1) captures the hypothesis of unconditional convergence, according to which countries' poverty rates converge with one another in the long run, independently of their initial conditions - that is, differences are transitory.

\subsection{Unconditional convergence in poverty levels and poverty eradication}

Fig. 1 presents simple scatter plots for our four poverty measures. Unconditional convergence is apparent in all cases, therefore suggesting that economies with higher poverty incidence in 1990 are expected to catch up with the economies having initial lower poverty. However, the significance and speed of the convergence process can be best assessed when referring to the regression estimates.

Panel (a) in Table 2 reports unconditional convergence estimates over the period 1990-2013 for poverty headcount and poverty gap, both at $1.25 \$$ and $2 \$$ a day. The estimates show that poverty levels have been converging since the 1990, with the coefficients on initial measures both negative and statistically significant at the one per cent level. In all regressions, measures of goodness of fit suggest that initial poverty levels explain substantial part of the variation in poverty reduction. To give an appreciation of the speed of convergence, consider the poverty headcount ratio at $\$ 1.25$ a day in 1990 in Mali (scoring 86.08) and Ecuador (scoring 6.79). The two countries are both on the regression line, but positioned nearly at its opposite extremes. According to the OLS estimates, the expected reduction in poverty will be -1.829 $-0.388 \times 86.08=-35.23$ percentage points in the former case and $-1.829-0.388 \times 6.79=-4.46$ in the latter. Such trends imply that, after 23 years, the two countries are predicted to reach a poverty headcount ratio at $\$ 1.25$ a day of $86.08-35.23=50.85$ and 6.79 $-4.46=2.33$, respectively. At this pace, it would take approximately three decades before Mali catches up with Ecuador. This is indicative of a significant process of convergence, although a slow one, where extreme poverty may still persist for generations.

What does this illustration suggest in terms of poverty eradication? Mali has reduced the poverty headcount ratio at $\$ 1.25$ a day at an average 1.53 points per year. At this pace, it is predicted to be at $86.08-38.29=47.79$ by the end of the MDGs period, so missing the target of halving the proportion of people in poverty, while it would take approximately another 31 years to eradicate extreme poverty altogether. The same simple arithmetic for Ecuador suggests that its Poverty headcount ratio at $\$ 1.25$ a day is predicted to be at $6.79-4.85=1.94$ by the end of the MDGs period, so meeting the target, while it would take approximately another 10 years to eradicate extreme poverty altogether. Repeating this exercise for the other indices leads to similar conclusions.

The foregoing illustrations fit the 'typical' country, on the regression line or close by. However, while they approximate well the

\footnotetext{
${ }^{8}$ Poverty convergence is defined in absolute terms in (1). It is a suitable statistical model to test our hypotheses, as, by definition, this captures the idea of poverty reduction and hence MDG Goal 1. Cuaresma et al. (2016) adopt this approach, arguing that such a specification has important advantages, compared to the log specification in Ravallion (2012) (i.e., based on poverty elasticity): (i) to be insensitive to low poverty incidence; (ii) to be more appealing in policy terms (as policy makers are usually interested in percentage point, not percentage changes of poverty rate); (iii) it does not need the strong requirement that countries starting out with a high incidence of absolute poverty should enjoy a higher subsequent growth rate in mean consumption and (hence) a higher proportionate rate of poverty reduction (as Cuaresma et al. (2016, p. 4) put it, "it requires that a country should be more likely to reduce poverty from 60 to $30 \%$ than from, say, 4 to $2 \%$ ").
}

trends of a significant part of our sample, our regressions may not be able to explain the situation of a number of countries, which, although showing similar levels of initial poverty, present substantial variations in their poverty reduction achievements. For example, take the following two groups of countries in Fig. 1: Nigeria, Lesotho, Madagascar, and Zambia; and China, Vietnam, Indonesia, Cambodia, and Pakistan. ${ }^{9}$ Initial headcount ratios at $1.25 \$$ and $2 \$$ a day were similar in both groups. Yet, the latter group has been successful in reducing poverty, the former has not. ${ }^{10}$ Could this reflect the role of structural conditions, such as the governance environment? This is where we turn our attention in the next two sections.

\section{Has poverty reduction accelerated with adoption of the MDGs?}

The results shown in Table 2 suggest that economies with higher poverty incidence in 1990 are expected to catch up with economies having initial lower poverty, independently of their initial conditions. But such trends, although welcome in terms of poverty eradication, do not yet explain the considerable variation in convergence and poverty reduction performance. What does explain this variation? As discussed in Section 1, there are two potential governance channels through which progress in poverty reduction during 1990-2015 could be mediated. In this section, we explore the first type of governance mechanism, which operates at the international level. It is possible that the convergence process may have changed pace since the year 2000. The adoption of the MDGs, and the ensuing renewed effort to tackle poverty, could have accelerated convergence and hence started a process fostering poverty reduction. ${ }^{11}$ The corresponding testable hypothesis is

\footnotetext{
9 Note that the case of Pakistan seems to be controversial. A recent analysis of official poverty data between 1990 and 2010 shows how the estimates may be biased, due to both technical flaws and to the 'politics of measurement'. Hence, it seems difficult to reach a definitive conclusion as to whether poverty was reduced and so assess the extent of progress on MDG Goal 1 (Khan, Naveed, Samman, Sarwar, \& Hoy, 2015). Note also that a significant number of developing economies in the World Bank poverty database have missing observations. The sample size of this study is in line with the most recent empirical exercises (e.g., Cuaresma et al., 2017; Ravallion, 2012) However, as an anonymous referee noted, it could be that the missing observations may disproportionally come from poor economies, often lacking the resources, the political or governance conditions (e.g., on-going conflict) to collect, on a regular basis, income surveys. The implications could be marginal or even stack the odds against our hypothesis. The missing observations, in this case, are likely to come from countries with low state capacity (see Williams, 2009), which would have high initial levels of income poverty and presumably have seen little poverty reduction (or even an increase) over the period 1990-2013. If the foregoing reasoning is correct, the missing observations should be placed approximately in the top-right corner of Fig. 1, together with Zambia, Nigeria, Lesotho, and Madagascar. This would confirm (or even reinforce) the idea that poverty convergence is different for countries with different initial governance conditions, and state capacity in particular.

${ }^{10}$ Note that, as both our dependent variable and key explanatory variable are approximations of their 'true' values, our regression estimates are likely to be affected by measurement error. This, in turn, stacks the odds against our findings. Measurement error in the initial value of poverty implies that the convergence parameter is subject to attenuation bias, and so underestimates the true extent of the speed of convergence in our regressions. Measurement error in the dependent variable, instead, implies that the estimated standard error of the estimated $\beta$ will be larger, hence making it more difficult to reject to the null that the estimated speed of convergence is not different from zero. Apart from this, the results are generally insensitive to using robust regression methods, such as Iteratively Reweighted Least Squares (panel b in Table 2), and to formal checks for influential and outlying observations. However, DFITS statistics do signal that Madagascar, Zambia, Nigeria, and Lesotho are potentially influential for the fit of the poverty headcount ratios. Similarly, DFBETA statistics find that Vietnam, China, and Pakistan are countries that appear influential for the magnitude of the convergence parameter of the poverty headcount ratios.

${ }^{11}$ While the MDG era has seen a significant decline in income poverty in the developing world, the much larger decline occurred well before the MDG goal setting. In the case of China, for example, which accounts for much of the reduction in global poverty, the MDGs only contributed a relatively small amount of the country's progress. The consensus view is that the reduction in global income poverty is mainly due to rapid growth, primarily in a few countries in Asia (Deaton, 2015; Fosu, 2017; Lomazzi, Borisch, \& Laaser, 2014).
} 

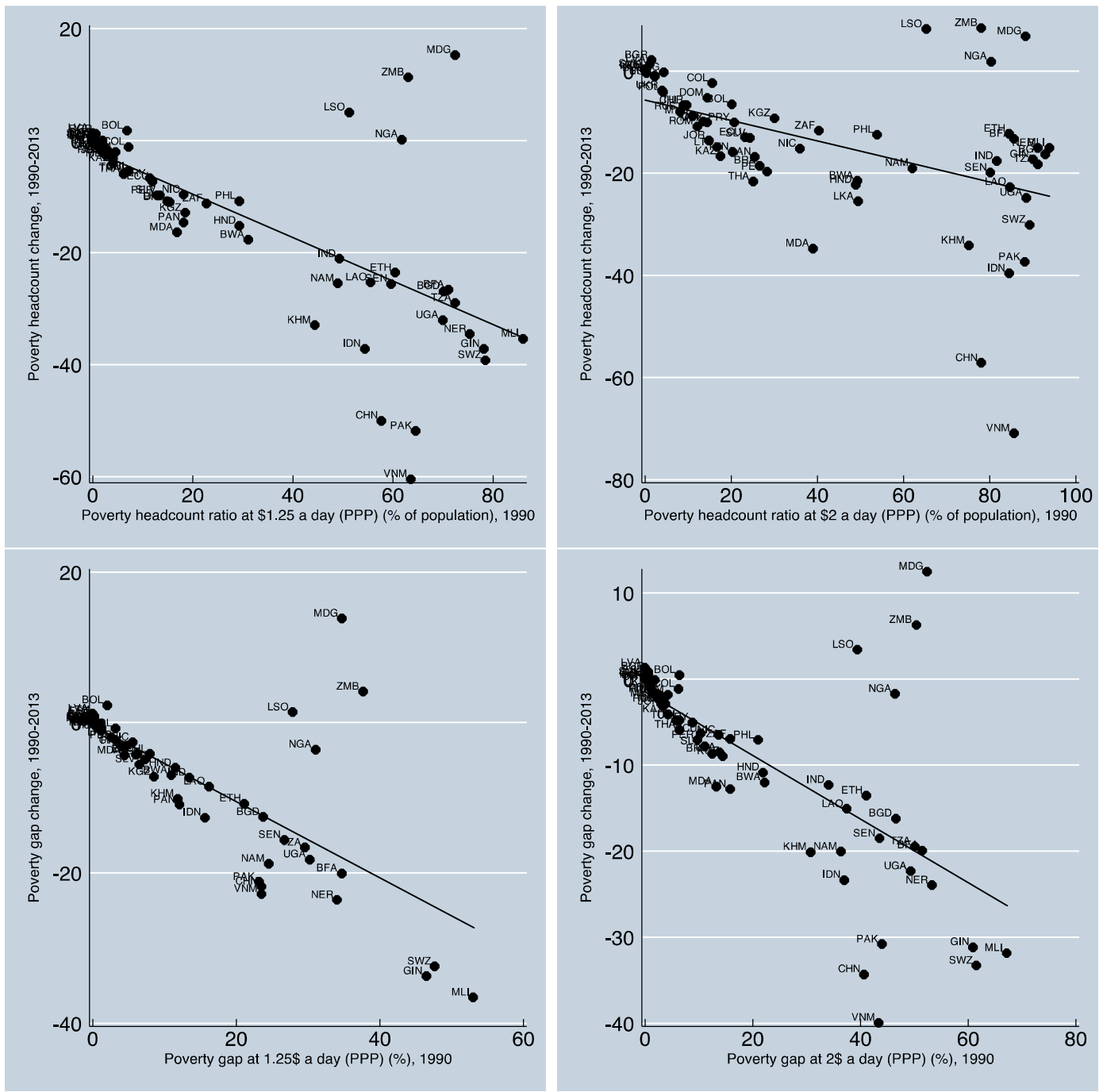

Fig. 1. Initial level of poverty vs. subsequent change: headcount and gap measures.

Table 2

Unconditional poverty convergence: OLS and iteratively reweighted least squares (IRLS) estimates.

\begin{tabular}{|c|c|c|c|c|}
\hline Dep. variable: & $\begin{array}{l}\text { Poverty headcount ratio at } \$ 1.25 \\
\text { a day (PPP) (\% of population) }\end{array}$ & $\begin{array}{l}\text { Poverty headcount ratio at } \$ 2 \\
\text { a day (PPP) (\% of population) }\end{array}$ & $\begin{array}{l}\text { Poverty gap at } \$ 1.25 \\
\text { a day (PPP) (\%) }\end{array}$ & $\begin{array}{l}\text { Poverty gap at } \$ 2 \\
\text { a day (PPP) }(\%)\end{array}$ \\
\hline \multicolumn{5}{|c|}{ Panel (a): OLS estimates } \\
\hline Initial value & $\begin{array}{l}-0.388^{* * *} \\
(0.066)\end{array}$ & $\begin{array}{l}-0.201^{* * *} \\
(0.053)\end{array}$ & $\begin{array}{l}-0.506^{* * *} \\
(0.098)\end{array}$ & $\begin{array}{l}-0.370^{* * *} \\
(0.067)\end{array}$ \\
\hline \multirow[t]{2}{*}{ Constant } & $-1.829^{* * *}$ & $-5.670^{* * *}$ & -0.404 & $-1.503^{* *}$ \\
\hline & $(0.674)$ & $(1.321)$ & $(0.488)$ & $(0.587)$ \\
\hline F-stat & $34.941^{* * *}$ & $14.139^{* * * *}$ & $26.939^{* * * *}$ & $30.004^{* * *}$ \\
\hline Adj. R-Sq. & 0.471 & 0.219 & 0.534 & 0.458 \\
\hline Obs. & 62 & 62 & 62 & 62 \\
\hline RMSE & 11.628 & 12.563 & 6.690 & 8.145 \\
\hline \multicolumn{5}{|c|}{ Panel (b): IRLS estimates } \\
\hline Dep. variable: & $\begin{array}{l}\text { Poverty headcount ratio at } \$ 1.25 \\
\text { a day (PPP) (\% of population) }\end{array}$ & $\begin{array}{l}\text { Poverty headcount ratio at } \$ 2 \\
\text { a day (PPP) (\% of population) }\end{array}$ & $\begin{array}{l}\text { Poverty gap at } \$ 1.25 \\
\text { a day (PPP) (\%) }\end{array}$ & $\begin{array}{l}\text { Poverty gap at } \$ 2 \\
\text { a day (PPP) }(\%)\end{array}$ \\
\hline \multirow[t]{2}{*}{ Initial value } & $-0.427^{* * *}$ & $-0.180^{* * *}$ & $-0.669^{* * * *}$ & $-0.447^{* * *}$ \\
\hline & $(0.014)$ & $(0.033)$ & $(0.015)$ & $(0.018)$ \\
\hline \multirow[t]{2}{*}{ Constant } & $-1.309^{* * *}$ & $-5.808^{* * *}$ & 0.172 & -0.836 \\
\hline & $(0.539)$ & $(1.747)$ & $(0.271)$ & $(0.514)$ \\
\hline F-stat & $1000.412^{* * *}$ & $30.661^{* * * *}$ & $2121.633^{* * *}$ & $642.623^{* * *}$ \\
\hline Adj. R-Sq. & 0.942 & 0.327 & 0.972 & 0.913 \\
\hline Obs. & 62 & 62 & 62 & 62 \\
\hline RMSE & 3.011 & 8.670 & 1.617 & 2.821 \\
\hline
\end{tabular}

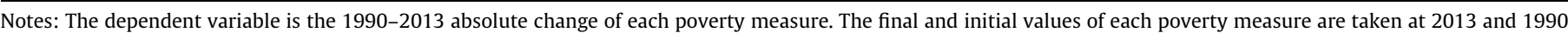

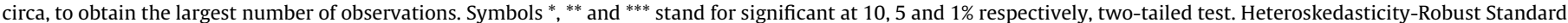
errors are in parentheses. 
that poverty convergence has accelerated since the adoption of MDGs, which is equivalent to testing whether the speed of convergence $\beta$ has been constant or has become larger in magnitude since 2000.

We do this by reinvestigating convergence with panel methods. We form an unbalanced panel (with $\mathrm{N}>\mathrm{T}$ ) by dividing the period under scrutiny into two (roughly 10-year) episodes: 1990-2000 and 2001-2013. Such temporal structures can capture whether the speed of convergence was faster in the period immediately following the MDG adoption, as compared to the preceding historical period. Our convergence regression in such a setting is:

$\Delta \mathrm{P}_{i t}=\alpha+\beta_{1} P_{i t}+\beta_{2} t+\beta_{3} t P_{i t}+\varepsilon_{i t}$ with $i=1, \ldots, \mathrm{N}$ and $\mathrm{t}=0,1$

The dependent variable in this case is the difference between the final and the initial poverty measure over each of the two episodes and $t$ is the time dummy, which takes value one to identify the MDG period (2001-2013) and value zero corresponds to the period leading to the MDG adoption (1990-2000), which is the omitted category. The interaction term, between the time dummy and the initial level of poverty, allows for testing for structural change in the convergence parameters over time. According to (2), the sign and magnitude of the effect of initial poverty levels on its subsequent change depends on the historical period. Hence, the marginal effect is $\beta_{1}+\beta_{3}$ t. If both $\beta_{1}$ and $\beta_{3}$ are negative, it would indicate that renewed policy efforts following the MDGs adoption have boosted poverty eradication.
Table 3 (panel a) presents Pooled OLS estimates for our four poverty measures (they are a test of unconditional convergence, when they do not control for any countries' structural characteristics). When such regressions include the interaction terms, they do not seem to indicate that there has been any stronger convergence for the 2001-2013 period, testifying of the insignificance of the MDG adoption. Incidentally, such results are very similar when the split the period of analysis in two identical sub-periods (i.e., 1991-2000 and 2001-2010).

To conclude that the adoption of the MDGs has meant no change in the pace of convergence would, however, be misleading. Like the initial set of results presented in Table 2, this second set of regressions also seems unable to explain the situation of a number of countries which, although showing similar levels of initial poverty, present large variations in poverty reduction experiences in both periods. A re-examination of the regressions shows that the finding that MDGs adoption had no effect on poverty convergence is not a general one. The speed of convergence appears to be the same as in the 1990s and the first decade of the next millennium, because of the effect of influential observations. For example, Fig. 2 shows that the slope of the speed of convergence in the 1990s may be driven by Turkmenistan, Mauritania, and Pakistan, which have been able to achieve a higher-than-expected reduction in poverty (given their initial level) in this decade. Similarly, in the first decade of the new millennium, the speed of convergence appears slower, because of the poor poverty reduction performance (relative to their initial level) of a set of Sub-Saharan African economies:

Table 3

Unconditional poverty convergence before and after MDGs adoption: Pooled OLS and IRLS estimates.

\begin{tabular}{|c|c|c|c|c|c|c|c|c|}
\hline \multirow[t]{2}{*}{ Dep. Variable: } & \multicolumn{2}{|c|}{$\begin{array}{l}\text { Poverty headcount ratio } \\
\text { at } \$ 1.25 \text { a day (PPP) (\% of } \\
\text { population) }\end{array}$} & \multicolumn{2}{|c|}{$\begin{array}{l}\text { Poverty headcount ratio } \\
\text { at } \$ 2 \text { a day (PPP) (\% of } \\
\text { population) }\end{array}$} & \multicolumn{2}{|c|}{$\begin{array}{l}\text { Poverty gap at } \$ 1.25 \text { a day } \\
\text { (PPP) (\%) }\end{array}$} & \multicolumn{2}{|c|}{$\begin{array}{l}\text { Poverty gap at } \$ 2 \text { a day } \\
(\mathrm{PPP})(\%)\end{array}$} \\
\hline & 1 & 2 & 1 & 2 & 1 & 2 & 1 & 2 \\
\hline \multicolumn{9}{|l|}{ Panel (a): Pooled OLS estimates } \\
\hline Initial value & $\begin{array}{l}-0.132^{* * *} \\
(0.044)\end{array}$ & $\begin{array}{l}-0.134^{* *} \\
(0.054)\end{array}$ & $\begin{array}{l}-0.077^{* * *} \\
(0.026)\end{array}$ & $\begin{array}{l}-0.093^{* * *} \\
(0.034)\end{array}$ & $\begin{array}{l}-0.132^{*} \\
(0.070)\end{array}$ & $\begin{array}{l}-0.140^{*} \\
(0.082)\end{array}$ & $\begin{array}{l}-0.113^{* *} \\
(0.045)\end{array}$ & $\begin{array}{l}-0.123^{* *} \\
(0.055)\end{array}$ \\
\hline 2001-2013 dummy & $\begin{array}{l}-4.842^{* * *} \\
(1.397)\end{array}$ & $\begin{array}{l}-4.940^{* * *} \\
(1.414)\end{array}$ & $\begin{array}{l}-7.560^{* * *} \\
(1.739)\end{array}$ & $\begin{array}{l}-8.775^{* * *} \\
(1.985)\end{array}$ & $\begin{array}{l}-1.833^{* *} \\
(0.811)\end{array}$ & $\begin{array}{l}-1.985^{* *} \\
(0.782)\end{array}$ & $\begin{array}{l}-3.515^{* * *} \\
(1.018)\end{array}$ & $\begin{array}{l}-3.889^{* * *} \\
(1.105)\end{array}$ \\
\hline Initial value * 2001-2013 dum. & & $\begin{array}{l}0.004 \\
(0.069)\end{array}$ & & $\begin{array}{l}0.031 \\
(0.044)\end{array}$ & & $\begin{array}{l}0.017 \\
(0.126)\end{array}$ & & $\begin{array}{l}0.021 \\
(0.074)\end{array}$ \\
\hline Constant & $\begin{array}{l}1.110 \\
(0.844)\end{array}$ & $\begin{array}{l}1.154 \\
(0.804)\end{array}$ & $\begin{array}{l}1.164 \\
(1.147)\end{array}$ & $\begin{array}{l}1.743 \\
(1.242)\end{array}$ & $\begin{array}{l}0.336 \\
(0.567)\end{array}$ & $\begin{array}{l}0.404 \\
(0.464)\end{array}$ & $\begin{array}{l}0.682 \\
(0.667)\end{array}$ & $\begin{array}{l}0.851 \\
(0.643)\end{array}$ \\
\hline F-stat & $10.766^{* * *}$ & $9.649^{* * *}$ & $12.700^{* * *}$ & $10.415^{* * *}$ & $3.993^{* *}$ & $5.924^{* * *}$ & $9.087^{* * *}$ & $9.097^{* * *}$ \\
\hline R-Squared & 0.177 & 0.171 & 0.173 & 0.169 & 0.097 & 0.090 & 0.151 & 0.145 \\
\hline Obs. & 137 & 137 & 137 & 137 & 137 & 137 & 137 & 137 \\
\hline RMSE & 8.668 & 8.700 & 9.836 & 9.861 & 4.872 & 4.890 & 6.124 & 6.144 \\
\hline Countries & 89 & 89 & 89 & 89 & 89 & 89 & 89 & 89 \\
\hline$\beta_{2001-2013}$ & & $-0.130^{* *}$ & & $-0.061^{*}$ & & -0.123 & & -0.102 \\
\hline \multicolumn{9}{|l|}{ Panel (b): IRLS estimates } \\
\hline \multirow[t]{2}{*}{ Dep. variable: } & \multicolumn{2}{|c|}{$\begin{array}{l}\text { Poverty headcount ratio } \\
\text { at } \$ 1.25 \text { a day (PPP) (\% of } \\
\text { population) }\end{array}$} & \multicolumn{2}{|c|}{$\begin{array}{l}\text { Poverty headcount ratio } \\
\text { at } \$ 2 \text { a day (PPP) (\% of } \\
\text { population) }\end{array}$} & \multicolumn{2}{|c|}{$\begin{array}{l}\text { Poverty gap at } \$ 1.25 \text { a day } \\
\text { (PPP) (\%) }\end{array}$} & \multicolumn{2}{|c|}{$\begin{array}{l}\text { Poverty gap at } \$ 2 \text { a day } \\
(\mathrm{PPP})(\%)\end{array}$} \\
\hline & 1 & 2 & 1 & 2 & 1 & 2 & 1 & 2 \\
\hline Initial value & $\begin{array}{l}-0.186^{* * *} \\
(0.021)\end{array}$ & $\begin{array}{l}-0.106^{* * *} \\
(0.024)\end{array}$ & $\begin{array}{l}-0.062^{* * *} \\
(0.022)\end{array}$ & $\begin{array}{l}-0.062^{*} \\
(0.032)\end{array}$ & $\begin{array}{l}-0.324^{* * *} \\
(0.018)\end{array}$ & $\begin{array}{l}-0.230^{* * *} \\
(0.020)\end{array}$ & $\begin{array}{l}-0.198^{* * *} \\
(0.021)\end{array}$ & $\begin{array}{l}-0.136^{* * *} \\
(0.025)\end{array}$ \\
\hline 2001-2013 dummy & $\begin{array}{l}-5.167^{* * *} \\
(1.040)\end{array}$ & $\begin{array}{l}-2.283^{*} \\
(1.194)\end{array}$ & $\begin{array}{l}-6.861^{* * *} \\
(1.385)\end{array}$ & $\begin{array}{l}-6.850^{* * *} \\
(2.212)\end{array}$ & $\begin{array}{l}-2.098^{* * *} \\
(0.389)\end{array}$ & $\begin{array}{l}-0.880^{* * *} \\
(0.404)^{* * *}\end{array}$ & $\begin{array}{l}-3.804^{* * *} \\
(0.725)\end{array}$ & $\begin{array}{l}-1.992^{* *} \\
(0.890)^{* * *}\end{array}$ \\
\hline Initial value * 2001-2013 dum. & & $\begin{array}{l}-0.200^{* * *} \\
(0.035)\end{array}$ & & $\begin{array}{l}-0.000 \\
(0.044)\end{array}$ & & $\begin{array}{l}-0.243^{* * *} \\
(0.029)\end{array}$ & & $\begin{array}{l}-0.160^{* * *} \\
(0.036)\end{array}$ \\
\hline Constant & $\begin{array}{l}1.750^{*} \\
(0.893)\end{array}$ & $\begin{array}{l}0.520 \\
(0.823)\end{array}$ & $\begin{array}{l}0.730 \\
(1.280)\end{array}$ & $\begin{array}{l}0.726 \\
(1.526)\end{array}$ & $\begin{array}{l}1.050^{* * *} \\
(0.326)\end{array}$ & $\begin{array}{l}0.533^{*} \\
(0.282)\end{array}$ & $\begin{array}{l}1.365^{* *} \\
(0.634)\end{array}$ & $\begin{array}{l}0.572 \\
(0.613)\end{array}$ \\
\hline F-stat & $53.528^{* * *}$ & $82.177^{* * *}$ & $17.477^{* * *}$ & $11.492^{* * *}$ & $174.44^{* * *}$ & $252.37^{* * *}$ & $60.190^{* * *}$ & $76.096^{* * *}$ \\
\hline R-Squared & 0.436 & 0.642 & 0.195 & 0.188 & 0.718 & 0.847 & 0.465 & 0.624 \\
\hline Obs. & 137 & 137 & 137 & 137 & 137 & 137 & 137 & 137 \\
\hline RMSE & 6.073 & 4.983 & 8.071 & 8.126 & 2.274 & 1.784 & 4.232 & 3.606 \\
\hline Countries & 89 & 89 & 89 & 89 & 89 & 89 & 89 & 89 \\
\hline$\beta_{2001-2013}$ & & $-0.306^{* * *}$ & & $-0.062^{* *}$ & & $-0.472^{* * *}$ & & $-0.295^{* * *}$ \\
\hline
\end{tabular}

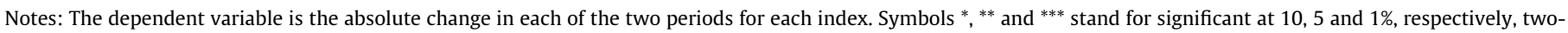
tailed test. Standard errors in OLS regressions, in parentheses, are robust for arbitrary heteroskedasticity and clustering at the country level. 

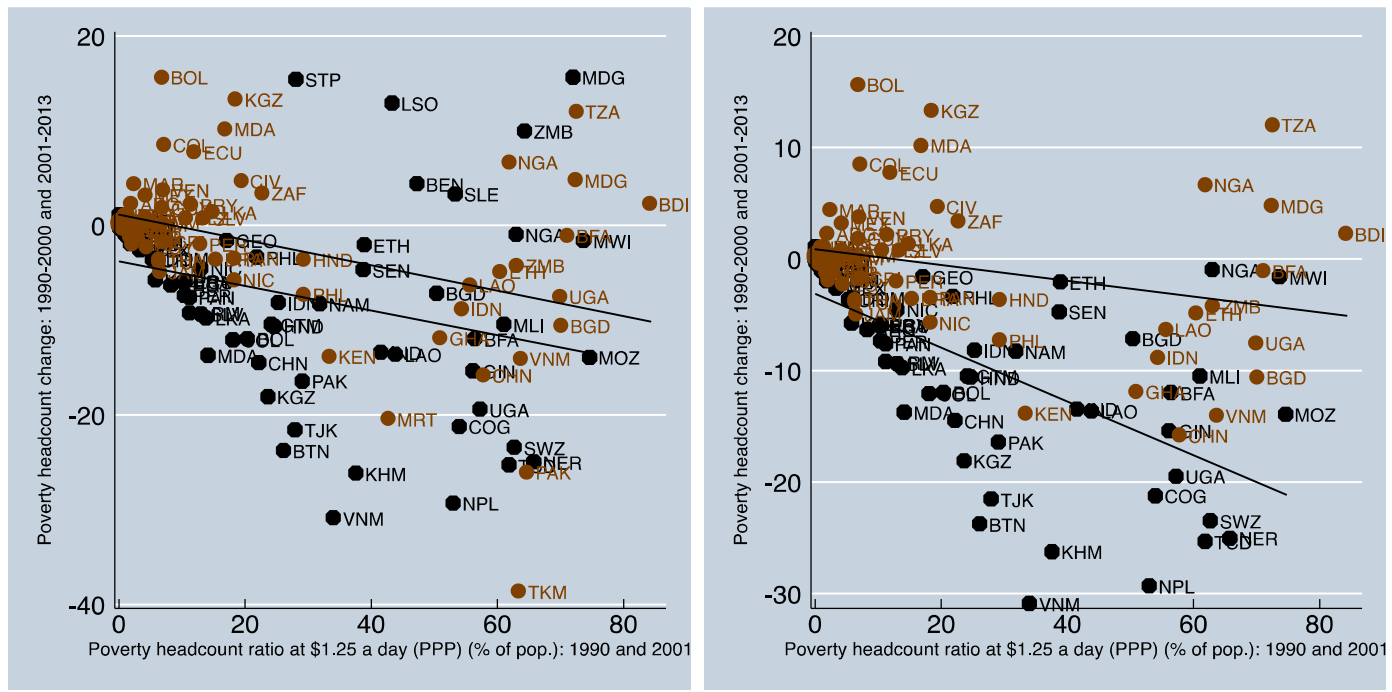

Fig. 2. Poverty headcount convergence in 1990-2000 (circles) and 2001-2013 (squares): with/without influential observations.

Madagascar, Zambia, Lesotho, Benin, Sierra Leone, and São Tomé and Príncipe.

When we formally re-estimate each of the above regressions using iteratively reweighted least squares (IRLS), giving zero weight to such influential observations, the results (reported in Panel (b) of Table 3) show that, post-MDG adoption, the speed of convergence has significantly accelerated, often doubling, apart from in one case. Incidentally, we obtain the same results when using median regression (not reported here, but available on request). This suggests, contrary to pooled OLS results, that the adoption of the MDGs may well have translated into more effective poverty reduction policies and therefore acceleration in the catchup process, but its effect may not be uniform across countries: as indicated by the significant variation in poverty reduction performance before and after the MDGs adoption. The implication is that looking at the role of changes in global governance is insufficient to explain the variation in poverty reduction experiences. This calls for further investigation: could the foregoing results reflect the role of structural conditions, such as the type of governance at national level?

\section{What explains the convergence process? The state capacity link}

Results on unconditional convergence tests suggest that differences in poverty levels between countries may be gradually closing. While on average poverty measures have converged, the average trends may still mask considerable variation in the experience of specific groups or individual countries. Similarly, changes in global development governance, such as the MDGs adoption, also seem to leave unexplained a lot of variation in poverty reduction performance. Would the poverty reduction process be faster for countries with different structural characteristics? We investigate this possibility with respect to aspects of governance quality at national level, as the effects of changes of governance at the international level may or may not be effectively reflected in individual countries' poverty eradication policies, depending on the underlying governance conditions at national level needed to accelerate poverty reduction. This implies allowing for an interaction term between governance measures and the initial poverty level in (conditional) convergence regressions. This is equivalent to estimating a modified version of (1), which now includes a multiplicative term, thus becoming a conditional convergence regression. $^{12}$

Deficiencies in the national governance infrastructure may reduce the ability of countries to deliver poverty-reduction policies and to create an investment climate that stimulates economic growth, thus also damaging prospects of poverty reduction through an indirect channel. Hence, there could be no poverty 'catch up'. But which governance dimension matters? The recent literature has emphasized the role of states and their institutional capability to deliver policies benefiting their citizenry, i.e., state capacity. One argument has emphasized the capability to collect revenues, and to build the legal infrastructure guaranteeing a secure contractual environment, as two 'pillars' of economic development (Besley \& Persson, 2011). In particular, ruling elites that face a stronger incentive to develop such capacities are subject to a greater extent of constitutional limits on the exercise of their power (Besley \& Persson, 2011). We capture this as the value of Constraints on the Executive from the Polity IV dataset in 1990 (Marshall, Jaggers, \& Gurr, 2011). This variable measures to what extent the executive power is subject to institutionalized checks and balances (on a scale from one to seven, where one indicates unlimited authority of the chief executive and seven indicates executive parity or subordination, with intermediate values indicating moderate to substantial power limitations).

A second argument has stressed the capacity of states to resolve coordination failures (Bardhan, 2005, 2016) and to administer their territory in order to deliver goods and services to their citizens (Evans \& Rauch, 1999), where a longer history of statehood leads to higher quality administration through experience (Bockstette et al., 2002). The effect of length of statehood is captured by the state antiquity index (v. 3.1), proposed by Bockstette et al. (2002) and based on the intuition that longer histories of statehood lead to higher quality administration, due to two types of effect. One is due to learning-by-doing effects in the public administration, in which case long-standing states, with larger pools of experienced personnel, may do what they do better than newly formed states. The second type of effect relates to the length of operation of state institutions, which may support the development of attitudes consistent with bureaucratic discipline and hierarchical control, mak-

\footnotetext{
12 We estimate: $P_{i D}-P_{i 0}=\alpha+\beta_{1} P_{i 0}+\beta_{2} G_{i 0}+\beta_{3} P_{i 0} G_{i 0}+\varepsilon_{i}$, where $G_{i 0}$ is a measure of governance quality in country $i$ at $t=0$. Hence, the speed of convergence is: $\beta_{1}+\beta_{3} G_{i 0}$.
} 
Table 4

Conditional poverty convergence: accounting for the role of state capacity, OLS estimates.

\begin{tabular}{|c|c|c|c|c|c|c|c|c|c|c|}
\hline \multirow[t]{2}{*}{ Dep. variable: } & \multicolumn{5}{|c|}{ Poverty headcount ratio at $\$ 1.25$ a day (PPP) (\% of population) } & \multicolumn{5}{|c|}{ Poverty headcount ratio at $\$ 2$ a day (PPP) (\% of population) } \\
\hline & 1 & 2 & 3 & 4 & 5 & 1 & 2 & 3 & 4 & 5 \\
\hline \multicolumn{11}{|c|}{ Panel (a): poverty headcount } \\
\hline Initial value & $\begin{array}{l}-0.324^{* *} \\
(0.141)\end{array}$ & $\begin{array}{l}-0.416^{* * *} \\
(0.100)\end{array}$ & $\begin{array}{l}-0.298^{* *} \\
(0.139)\end{array}$ & $\begin{array}{l}-0.497^{* * *} \\
(0.145)\end{array}$ & $\begin{array}{l}-0.068 \\
(0.222)\end{array}$ & $\begin{array}{l}-0.252^{* *} \\
(0.111)\end{array}$ & $\begin{array}{l}-0.256^{*} \\
(0.131)\end{array}$ & $\begin{array}{l}-0.098 \\
(0.125)\end{array}$ & $\begin{array}{l}-0.356^{* *} \\
(0.141)\end{array}$ & $\begin{array}{l}0.171 \\
(0.188)\end{array}$ \\
\hline State history & $\begin{array}{l}3.756 \\
(4.304)\end{array}$ & & $\begin{array}{l}4.990 \\
(5.079)\end{array}$ & $\begin{array}{l}7.321 \\
(6.768)\end{array}$ & $\begin{array}{l}1.891 \\
(5.257)\end{array}$ & $\begin{array}{l}2.208 \\
(6.648)\end{array}$ & & $\begin{array}{l}3.956 \\
(6.188)\end{array}$ & $\begin{array}{l}8.625 \\
(10.434)\end{array}$ & $\begin{array}{l}-3.627 \\
(7.698)\end{array}$ \\
\hline State history * In. value & $\begin{array}{l}-0.662^{* * *} \\
(0.229)\end{array}$ & & $\begin{array}{l}-0.681^{* *} \\
(0.263)\end{array}$ & $\begin{array}{l}-0.596^{* * *} \\
(0.195)\end{array}$ & $\begin{array}{l}-0.635^{* *} \\
(0.267)\end{array}$ & $\begin{array}{l}-0.408^{* *} \\
(0.191)\end{array}$ & & $\begin{array}{l}-0.426^{* *} \\
(0.194)\end{array}$ & $\begin{array}{l}-0.359^{*} \\
(0.209)\end{array}$ & $\begin{array}{l}-0.393^{*} \\
(0.217)\end{array}$ \\
\hline Cons. on the Executive & & $\begin{array}{l}1.602^{* *} \\
(0.649)\end{array}$ & $\begin{array}{l}0.800 \\
(0.595)\end{array}$ & $\begin{array}{l}1.251 \\
(0.828)\end{array}$ & & & $\begin{array}{l}2.775^{* * *} \\
(0.805)\end{array}$ & $\begin{array}{l}2.485^{* * *} \\
(0.832)\end{array}$ & $\begin{array}{l}2.590^{* *} \\
(1.129)\end{array}$ & \\
\hline Cons. Exec. ${ }^{*}$ In. value & & $\begin{array}{l}-0.020 \\
(0.035)\end{array}$ & $\begin{array}{l}0.001 \\
(0.035)\end{array}$ & $\begin{array}{l}0.026 \\
(0.027)\end{array}$ & & & $\begin{array}{l}-0.031^{*} \\
(0.017)\end{array}$ & $\begin{array}{l}-0.026 \\
(0.022)\end{array}$ & $\begin{array}{l}0.001 \\
(0.021)\end{array}$ & \\
\hline Constant & $\begin{array}{l}50.645^{*} \\
(25.747)\end{array}$ & $\begin{array}{l}37.208 \\
(22.337)\end{array}$ & $\begin{array}{l}49.539^{*} \\
(25.989)\end{array}$ & $\begin{array}{l}18.194 \\
(24.272)\end{array}$ & $\begin{array}{l}59.853 \\
(42.052)\end{array}$ & $\begin{array}{l}74.027^{* *} \\
(30.650)\end{array}$ & $\begin{array}{l}68.449^{* *} \\
(29.819)\end{array}$ & $\begin{array}{l}64.490 \\
(30.093)\end{array}$ & $\begin{array}{l}32.266 \\
(29.958)\end{array}$ & $\begin{array}{l}89.376 \\
(42.282)\end{array}$ \\
\hline F-stat & $21.77^{* * *}$ & $11.65^{* * *}$ & $15.53^{* * *}$ & $18.84^{* * *}$ & $11.01^{* * *}$ & $7.69^{* * *}$ & $9.51^{* * *}$ & $8.61^{* * *}$ & $8.88^{* * *}$ & $8.38^{* * *}$ \\
\hline Adj. R-Sq. & 0.615 & 0.458 & 0.606 & 0.813 & 0.595 & 0.435 & 0.300 & 0.439 & 0.622 & 0.560 \\
\hline Obs. & 60 & 60 & 60 & 52 & 48 & 60 & 60 & 60 & 52 & 48 \\
\hline RMSE & 9.947 & 11.795 & 10.056 & 6.418 & 10.461 & 10.844 & 12.068 & 10.810 & 7.750 & 9.629 \\
\hline Controls & Yes & Yes & Yes & Yes & Yes & Yes & Yes & Yes & Yes & Yes \\
\hline \multicolumn{10}{|l|}{ Panel (b): poverty gap } & Poverty gap at \$2 a day (PPP) (\%) \\
\hline & 1 & 2 & 3 & 4 & 5 & 1 & 2 & 3 & 4 & 5 \\
\hline Initial value & $\begin{array}{l}-0.455^{* *} \\
(0.175)\end{array}$ & $\begin{array}{l}-0.662^{* * *} \\
(0.148)\end{array}$ & $\begin{array}{l}-0.605^{* * *} \\
(0.164)\end{array}$ & $\begin{array}{l}-0.762^{* * *} \\
(0.131)\end{array}$ & $\begin{array}{l}-0.031 \\
(0.387)\end{array}$ & $\begin{array}{l}-0.360^{* *} \\
(0.143)\end{array}$ & $\begin{array}{l}-0.437^{* * *} \\
(0.096)\end{array}$ & $\begin{array}{l}-0.377^{* *} \\
(0.141)\end{array}$ & $\begin{array}{l}-0.560^{* * *} \\
(0.145)\end{array}$ & $\begin{array}{c}-0.003 \\
(0.241)\end{array}$ \\
\hline State history & $\begin{array}{l}1.253 \\
(2.787)\end{array}$ & & $\begin{array}{l}3.003 \\
(3.434)\end{array}$ & $\begin{array}{l}4.886 \\
(3.891)\end{array}$ & $\begin{array}{l}3.338 \\
(3.013)\end{array}$ & $\begin{array}{l}2.900 \\
(3.332)\end{array}$ & & $\begin{array}{l}4.258 \\
(4.010)\end{array}$ & $\begin{array}{l}6.707 \\
(5.542)\end{array}$ & $\begin{array}{l}2.304 \\
(3.875)\end{array}$ \\
\hline State history * In. value & $\begin{array}{l}-0.758^{* *} \\
(0.343)\end{array}$ & & $\begin{array}{l}-0.868^{* *} \\
(0.401)\end{array}$ & $\begin{array}{l}-0.868^{* * *} \\
(0.277)\end{array}$ & $\begin{array}{l}-0.815^{* *} \\
(0.388)\end{array}$ & $\begin{array}{l}-0.589^{* *} \\
(0.240)\end{array}$ & & $\begin{array}{l}-0.627^{* *} \\
(0.277)\end{array}$ & $\begin{array}{l}-0.592^{* * *} \\
(0.216)\end{array}$ & $\begin{array}{l}-0.599^{* *} \\
(0.284)\end{array}$ \\
\hline Cons. on the Executive & & $\begin{array}{l}0.123 \\
(0.383)\end{array}$ & $\begin{array}{l}-0.326 \\
(0.413)\end{array}$ & $\begin{array}{l}-0.001 \\
(0.546)\end{array}$ & & & $\begin{array}{l}1.027^{* *} \\
(0.461)\end{array}$ & $\begin{array}{l}0.394 \\
(0.469)\end{array}$ & $\begin{array}{l}0.703 \\
(0.649)\end{array}$ & \\
\hline Cons. Exec. ${ }^{*}$ In. value & & $\begin{array}{l}0.044 \\
(0.066)\end{array}$ & $\begin{array}{l}0.069 \\
(0.067)\end{array}$ & $\begin{array}{l}0.092^{* *} \\
(0.045)\end{array}$ & & & $\begin{array}{l}-0.005 \\
(0.035)\end{array}$ & $\begin{array}{l}0.016 \\
(0.038)\end{array}$ & $\begin{array}{l}0.040 \\
(0.029)\end{array}$ & \\
\hline Constant & $\begin{array}{l}25.538^{*} \\
(13.239)\end{array}$ & $\begin{array}{l}7.909 \\
(8.047)\end{array}$ & $\begin{array}{l}21.348^{*} \\
(11.607)\end{array}$ & $\begin{array}{l}7.414 \\
(11.307)\end{array}$ & $\begin{array}{l}10.539 \\
(18.102)\end{array}$ & $\begin{array}{l}39.847^{* *} \\
(18.769)\end{array}$ & $\begin{array}{l}25.359^{*} \\
(13.208)\end{array}$ & $\begin{array}{l}38.554^{* *} \\
(18.670)\end{array}$ & $\begin{array}{l}15.382 \\
(18.485)\end{array}$ & $\begin{array}{l}34.458 \\
(27.653)\end{array}$ \\
\hline F-stat & $23.45^{* * *}$ & $12.63^{* * *}$ & $11.20^{* * *}$ & $44.90^{* * *}$ & $26.50^{* * * *}$ & $19.42^{* * *}$ & $11.72^{* * *}$ & $13.28^{* * *}$ & $22.44^{* * *}$ & $12.24^{* * *}$ \\
\hline Adj. R-Sq. & 0.590 & 0.521 & 0.607 & 0.865 & 0.555 & 0.565 & 0.450 & 0.563 & 0.793 & 0.557 \\
\hline Obs. & 60 & 60 & 60 & 52 & 48 & 60 & 60 & 60 & 52 & 48 \\
\hline RMSE & 6.236 & 6.742 & 6.109 & 3.533 & 6.576 & 7.303 & 8.215 & 7.321 & 4.732 & 7.465 \\
\hline Controls & Yes & Yes & Yes & Yes & Yes & Yes & Yes & Yes & Yes & Yes \\
\hline
\end{tabular}

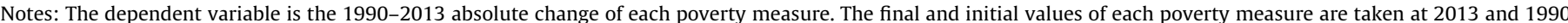

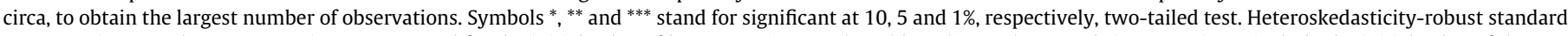

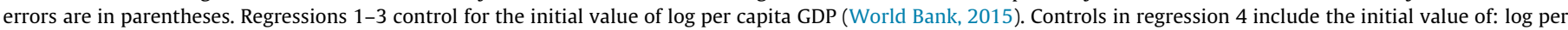

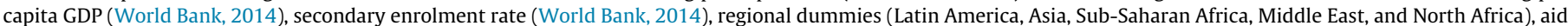

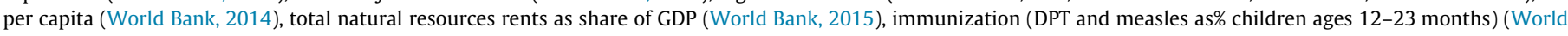

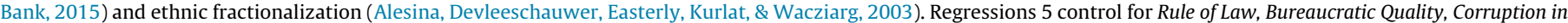
Government (ICRG, 2012) and their interactions with the initial poverty level, as well as the initial value of log per capita GDP (World Bank, 2014).

ing for greater organizational effectiveness. The index is constructed by observing state history over the period from 1 to 1950 AD. For each 50-year period, each country has been allocated a score for the existence of a government above tribal level; whether the government is locally based or foreign; and how much of the territory of the modern country was ruled by this government. The scores for each 50 -year sub-period have been multiplied by one another and then summed by weighting down the periods in the more remote past.

The results (Table 4) show evidence of stronger (conditional) convergence in countries with longer history of statehood. This seems to unambiguously support the idea that states with a greater ability to administer their territory and to resolve coordination failures created the conditions for a faster poverty reduction in the period under scrutiny. ${ }^{13}$ Therefore, addressing such failures may be an important link between MDGs and the Post-2015 Agenda. We find

\footnotetext{
${ }^{13}$ Compared with the goodness of fit in Table 2 regressions, Table 4 regressions show a substantial increase in R-squared, supporting the idea that initial conditions explain a significant part of the variation in poverty reduction. This is especially the case when introducing the state history-initial poverty interaction term.
}

no similar evidence, instead, with respect to fiscal and legal capacities of states. Such evidence does not deny the importance of fiscal and legal capacities of states, which may well have a longer-term effect on poverty through fostering economic growth or indeed consolidating state development. It rather more modestly suggests that, in the period under scrutiny, aspects of administrative capacity over the national territory have had a more prominent role in delivering poverty reduction polices in the attempt to reach Goal 1.

What is the effect of having longer state history? The magnitude of the speed of convergence is no longer constant, but depends on the length of statehood in different countries. Using the estimates from regressions 4, Figs. 3 and 4 calculate and report the estimated effects of the convergence parameter on poverty at the observed values of the length of statehood index. For all countries and poverty measures, there is a significant poverty-reducing effect, ceteris paribus. Countries starting with higher poverty levels have seen a larger reduction over 1990-2013, so converging to the poverty levels of economies where poverty has been eradicated. However, countries with a longer state history have experienced a faster reduction in poverty and, hence, faster convergence. In particular, the convergence parameter in the group of countries with the longest 


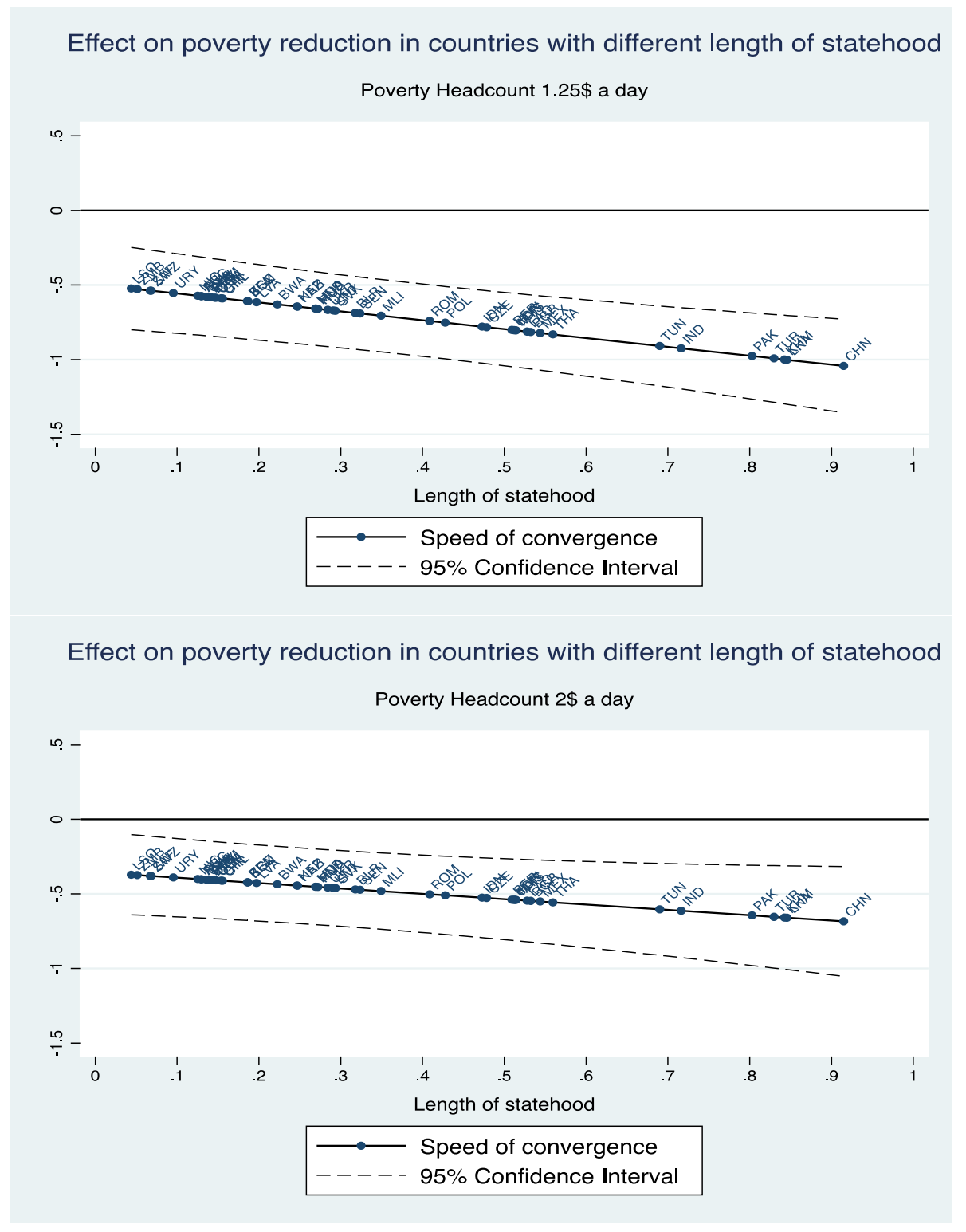

Fig. 3. Poverty headcount: speed of convergence with changing length of statehood.

state history is estimated to be approximately double the size of that in the group with shortest state history, for the four poverty measures considered. Among the countries that fall within the former group are: China, Cambodia, Indonesia, and Turkey. Countries falling within the latter are Sub-Saharan African economies: Lesotho, Zambia, Zimbabwe, and Swaziland. Interestingly, most of them are countries earlier identified (see Figs. 1 and 2) as cases whose poverty reduction performance could not be explained by convergence regressions, even when accounting for the effect of MDGs adoption.

\subsection{Robustness checks}

The above results are confirmed after conducting a series of checks for robustness. The key results hold true when introducing a series of controls to check whether the "state capacity effect" was due to other omitted structural characteristics. These controls are also important because natural constraints may hinder countries from achieving the MDG targets as they approach their upper or lower bound limits (Hailu \& Tsukada, 2011). First and foremost, we control for the initial level of income, capturing the stage of development (regressions 1, 2 and 3). Such results do not significantly change when also controlling for regional dummies, dependence on natural resources, education, and health inputs, dependence of foreign aid, and ethnic fractionalization, as a proxy for cultural heterogeneity (regressions 4). Second, we ask whether the length of statehood-poverty interaction is the only one at work (regressions 5). The length of statehood variable is historical in nature and may perhaps be considered exogenous. However, one could argue that the state history characteristics affecting the speed of poverty convergence could reflect some other element of the governance environment. To capture this possibility, we introduce further interaction terms constructed using the rule of law, corruption in government, and bureaucratic quality indices from the International Country Risk Guide (ICRG, 2012). As a consequence, the sign and magnitude of the length of statehood-poverty interaction remain stable; its significance marginally changes in one case. Finally, when we re-estimate the above regressions using IRLS and median regression, the results (not reported here, but available on request) show similar findings. 
Effect on poverty reduction in countries with different length of statehood Poverty Gap $1.25 \$$ a day

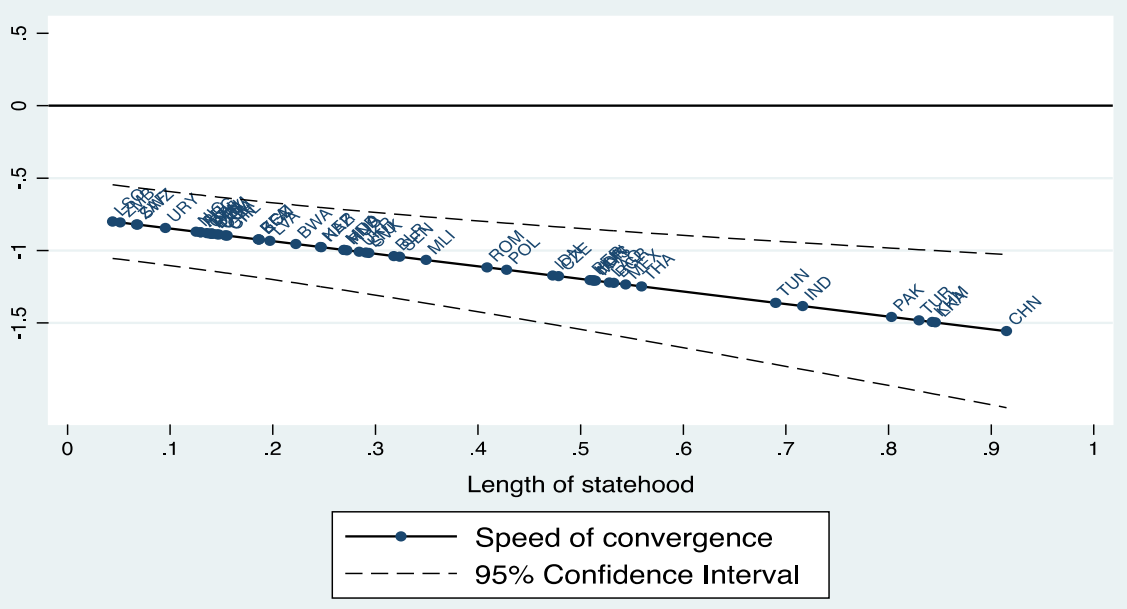

Effect on poverty reduction in countries with different length of statehood Poverty Gap $2 \$$ a day

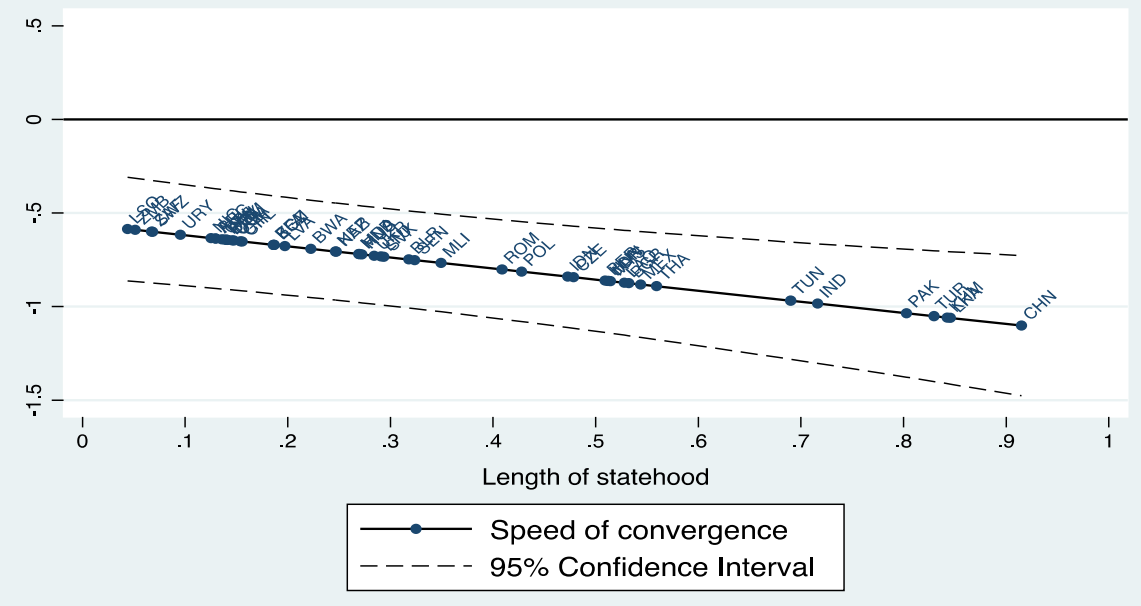

Fig. 4. Poverty gap: speed of convergence with changing length of statehood.

\section{Conclusions}

This paper offers a systematic re-assessment of the poverty eradication achievements, by producing evidence on whether, and how fast, economies with higher income poverty levels experienced larger reductions in their poverty rates, so as to close the gap with economies with lower income poverty levels (i.e., poverty convergence). We do so by focusing on the roles of MDGs adoption and of state capacity. Adoption of the MDGs has led to the emergence of a new norm of eradicating global poverty and has influenced national development plans, e.g., with the introduction of Poverty Reduction Strategy Papers (Fukuda-Parr \& Hulme, 2011; Hulme, 2015). Therefore, we test for a sample of developing countries whether MDGs adoption may have accelerated progress towards halving poverty, comparing differences in poverty reduction in the period before (1990-2000) and after (2001-2013) adoption. At the same time, we provide evidence on the impact of state capacity, an under-researched aspect in the quest for the determinants of MDG Goal 1, because the effects of MDGs adoption may or may not be reflected in individual countries' poverty eradication policies, depending on the ability of their states to design and deli- ver policies. State capacity deficits may reduce the ability of countries both to deliver poverty-reduction policies and to create an investment climate that stimulates economic growth, so also damaging the prospect of poverty reduction through an indirect channel. With this exercise, we contribute to the broader literature on the analysis of the MDGs as instruments of achieving specific global development targets (e.g., Dalgaard \& Erickson, 2009; Fiszbein et al., 2014; Fukuda-Parr, Greenstein, \& Stewart, 2013; Hailu \& Tsukada, 2011; Sumner \& Tiwari, 2009; Waage et al., 2010), offering new evidence on the income poverty-reducing effect of MDGs adoption and showing that such an effect depends also on the quality of national governance. ${ }^{14}$

\footnotetext{
${ }^{14}$ When assessed in non-income dimensions of poverty, the progress during the MDG era has been less dramatic in terms of reduction in hunger, food security, and malnutrition. In the case of South Asia, despite a steep decline in poverty, the region's share in the total number of undernourished population in the world has increased (Sharma, Dwivedi, \& Singh, 2016). Similarly, Sub-Saharan Africa's share in the global population of hungry people has increased. Convergence in multi-dimensional poverty may be slower and more responsive to political factors such as governance and state capacity. This issue is not addressed in our paper and is left for follow-up research.
} 
Our cross-section and panel convergence regressions, covering up to 89 developing economies during 1990-2013, find evidence of unconditional convergence in poverty headcount and gap measures (in line with Cuaresma et al., 2016, 2017). When comparing the periods before and after the MDGs adoption, the results show that that the speed of poverty convergence accelerated, so suggesting that MDGs adoption was instrumental to poverty reduction. Such findings are good news for halving poverty targets and for the Post-2015 Agenda, where the goal of reducing global poverty remains central.

However, such results also leave unexplained significant variation in poverty reduction performance across countries. To explain this, we look at the role of state capacity. Conditional convergence estimates find that, for a significant number of developing countries, the variation in poverty reduction performance is indeed explained by the challenge of poor governance at national level: the ability of states to administer their territory seems to be a structural characteristic that can accelerate the poverty 'catch-up' amongst economies. Countries that suffered from such state capacity deficit in 1990 were less likely to have achieved the MDG target on poverty reduction. Our results suggest, in line with previous studies (e.g., Cingolani et al., 2015; Cook, 2006; Harttgen \& Klasen, 2013; Imai et al., 2010; Kwon \& Kim, 2014; Smith \& Haddad, 2015), that the quality of governance matters for achieving the MDGs. However, documenting the impact of state capacity and identifying it as a structural condition facilitating poverty reduction are significant points of departure from previous findings.

As good governance and effective institutions are included in the Post-2015 development goals, this result provides empirical justification for this move, suggesting that states with a greater ability to administer their territory created the conditions for faster poverty reduction. The main lesson for the Post-2015 Agenda is that effective states could be crucial to sustain development progress achieved so far.

\section{Conflict of interest statement}

None.

\section{Acknowledgements}

The paper has enormously benefited from conversations with Prof. David Hulme and Prof. Kunal Sen. We thank the editor, Prof. Arun Agrawal, and two anonymous referees for their comments. All errors remain our own.

\section{Appendix}

Table A1. List of countries.

\begin{tabular}{lll}
\hline Albania ALB & Ghana GHA & Nigeria NGA \\
\hline Argentina ARG & $\begin{array}{l}\text { Guatemala } \\
\text { GTM }\end{array}$ & Pakistan PAK \\
$\begin{array}{l}\text { Grmenia ARM } \\
\text { Azerbaijan AZE }\end{array}$ & $\begin{array}{l}\text { Guyanea GIN } \\
\text { Hony }\end{array}$ & $\begin{array}{l}\text { Panama PAN } \\
\text { Papua New Guinea } \\
\text { PNG }\end{array}$ \\
Bangladesh BGD & Honduras & Paraguay PRY \\
Belarus BLR & HND & \\
Belize BLZ & Hungary HUN & Peru PER \\
Benin BEN & India IND & Philippines PHL \\
Bhutan BTN & Indonesia IDN & Poland POL \\
& Iran IRN & Romania ROM
\end{tabular}

Table A1 (continued)

\begin{tabular}{|c|c|c|}
\hline Albania ALB & Ghana GHA & Nigeria NGA \\
\hline Bolivia BOL & $\begin{array}{l}\text { Ivory Coast } \\
\text { CIV }\end{array}$ & Russia RUS \\
\hline $\begin{array}{l}\text { Bosnia-Herzegovina } \\
\text { BIH }\end{array}$ & Jamaica JAM & Rwanda RWA \\
\hline Botswana BWA & Jordan JOR & $\begin{array}{l}\text { São Tomé and } \\
\text { Príncipe STP }\end{array}$ \\
\hline Brazil BRA & $\begin{array}{l}\text { Kazakhstan } \\
\text { KAZ }\end{array}$ & Senegal SEN \\
\hline Bulgaria BGR & Kenya KEN & Sierra Leone SLE \\
\hline Burkina Faso BFA & $\begin{array}{l}\text { Kirghizstan } \\
\text { KGZ }\end{array}$ & Slovak Rep. SVK \\
\hline Burundi BDI & Laos LAO & Slovenia SVN \\
\hline Cambodia KHM & Latvia LVA & South Africa ZAF \\
\hline Cameroon CMR & Lesotho LSO & Sri Lanka LKA \\
\hline $\begin{array}{l}\text { Central African } \\
\text { Republic CAF }\end{array}$ & Lithuania LTU & Sudan SDN \\
\hline Chile CHL & $\begin{array}{l}\text { Macedonia } \\
\text { MKD }\end{array}$ & Swaziland SWZ \\
\hline China CHN & $\begin{array}{l}\text { Madagascar } \\
\text { MDG }\end{array}$ & Tanzania TZA \\
\hline Colombia COL & Malawi MWI & Thailand THA \\
\hline Costa Rica CRI & Malaysia MYS & Tunisia TUN \\
\hline Croatia HRV & Mali MLI & Turkey TUR \\
\hline Czech Rep. CZE & $\begin{array}{l}\text { Mauritania } \\
\text { MRT }\end{array}$ & Turkmenistan TKM \\
\hline $\begin{array}{l}\text { Dominican Republic } \\
\text { DOM }\end{array}$ & Mexico MEX & Uganda UGA \\
\hline Ecuador ECU & Moldova MDA & Ukraine UKR \\
\hline Egypt EGY & Morocco MAR & Uruguay URY \\
\hline El Salvador SLV & $\begin{array}{l}\text { Mozambique } \\
\text { MOZ }\end{array}$ & Venezuela VEN \\
\hline Estonia EST & Namibia NAM & Vietnam VNM \\
\hline Ethiopia ETH & Nepal NPL & Zambia ZMB \\
\hline Fiji FJI & Nicaragua NIC & Zimbabwe ZWE \\
\hline Georgia GEO & Niger NER & \\
\hline
\end{tabular}

\section{References}

Acemoglu, D., Johnson, S., \& Robinson, J. R. (2001). The colonial origins of comparative development: an empirical investigation. The American Economic Review, 91, 1369-1401. https://doi.org/10.3386/w7771.

Addison, T., Niño-Zarazúa, M., \& Tarp, F. (2015). Aid, social policy and development. Journal of International Development, 27(8), 1351-1365. https://doi.org/10.1002/ jid.3187.

Alesina, A., Devleeschauwer, A., Easterly, W., Kurlat, S., \& Wacziarg, R. (2003). Fractionalization. Journal of Economic Growth, 8(2), 155-194. https://doi.org/ 10.1023/A:102447150.

Asadullah, M. Niaz, Savoia, A., \& Wahiduddin, M. (2014). Paths to development: Is there a Bangladesh Surprise? World Development, 62, 138-154. https://doi.org/ 10.1016/j.worlddev.2014.05.013.

Baland, J.-M., Moene, K. O., \& Robinson, J. A. (2010). Governance and development In D. Rodrick \& M. R. Rosenzweig (Eds.). Chapter 69 Handbook of development economics (vol. 5, pp. 4597-4656). Amsterdam: Elsevier/North Holland (Chapter 68).

Bardhan, P. (2005). Institutions matter, but which ones? Economics of Transition, 13 (3), 499-532. https://doi.org/10.1111/j.1468-0351.2005.00229.x.

Bardhan, P. (2016). State and development: the need for a reappraisal of the current literature. Journal of Economic Literature, 54(3), 862-892. https://doi.org/ $10.1257 /$ jel.20151239.

Barro, R. J. (2015). Convergence and modernization. Economic Journal, 125(85), 911-942.

Besley, T., \& Persson, T. (2011). Pillars of prosperity: the political economics of development clusters. Princeton, NJ: Princeton University Press.

Bockstette, V., Chanda, A., \& Putterman, L. (2002). States and markets: The advantage of an early start. Journal of Economic Growth, 7, 347-369. https:// doi.org/10.1023/A:102082780. 
Booth, D. (Ed.) (2003). Are PRSPs making a difference? The African experience. Special issue of Development Policy Review, 21(2), 131-159.

Canning, D. (2012). Progress in health around the world. Journal of Development Studies, 48(12), 1784-1798. https://doi.org/10.1080/00220388.2012.663907.

Centeno, M. A., Kohli, A., \& Yashar, D. J. (2017). In Unpacking states in the developing world: Capacity, performance, and politics. In M. A. Centeno, A. Kohli, \& D. J. Yashar (Eds.). States in the developing world (Chapter 1). Cambridge: Cambridge University Press.

Cingolani, L., Thomsson, K., \& de Crombrugghe, D. (2015). Minding Weber more than ever? The impacts of state capacity and bureaucratic autonomy on development goals. World Development, 72, 191-207. https://doi.org/10.1016/ j.worlddev.2015.02.016.

Cook, S. (2006). Structural change, growth and poverty reduction in Asia: Pathways to inclusive development. Development Policy Review, 24(1), s51-80. https://doi. org/10.1111/j.1467-7679.2006.00341.x.

Cuaresma, J. C., Klasen, S., \& Wacker, K. M. (2016). There is poverty convergence. Department of Economics Working Papers wuwp213, Vienna University of Economics and Business, Department of Economics.

Cuaresma, J. C., Klasen, S., \& Wacker, K. M. (2017). Is there poverty convergence? GSME Discussion Paper number 1711, Johannes Gutenberg University Mainz.

Dalgaard, C. J., \& Erickson, L. (2009). Reasonable expectations and the first Millennium Development Goal: How much can aid achieve? World Development, 37(7), 1170-1181. https://doi.org/10.1016/ j.worlddev.2008.11.003.

Deaton, A. (2015). The Great Escape: Health, wealth, and the origins of inequality. Princeton, NJ: Princeton University Press.

Deaton, A. (2004). Health in an age of globalization. In Brookings. Trade (Ed.), Forum 2004: Globalization, poverty and inequality (pp. 83-130). Washington, DC: Brookings Institution Press.

Dincecco, M., \& Prado, M. (2013). Warfare, fiscal capacity and performance. Journal of Economic Growth, 17(3), 171-203. https://doi.org/10.2139/ ssrn. 1506890 .

Easterly, W. (2009). How the Millennium Development Goals are unfair to Africa. World Development, 37(1), 26-35. https://doi.org/10.1016/ j.worlddev.2008.02.009.

Elkins, M., Feeny, S., \& Prentice, D. (2017). Are Poverty Reduction Strategy Papers associated with reductions in poverty and improvements in wellbeing? The Journal of Development Studies. https://doi.org/10.1080/ 00220388.2017.1299140.

Evans, P. B., \& Rauch, J. E. (1999). Bureaucracy and growth: A cross-national analysis of the effects of 'Weberian' state structures on economic growth. American Sociological Review, 64(5), 748-765. https://doi.org/10.1177/ 0038038507076620.

Fiszbein, A., Kanbur, R., \& Yemtsov, R. (2014). Social protection and poverty reduction: Global patterns and some targets. World Development, 61, 167-177. https://doi.org/10.1016/j.worlddev.2014.04.010.

Fosu, A. K. (2017). Growth, inequality, and poverty reduction in developing countries: Recent global evidence. Research in Economics, 71(2), 306-336. https://doi.org/10.1016/j.rie.2016.05.005.

Fukuda-Parr, S. (2011). Theory and policy in international development: Human development and capability approach and the Millennium Development Goals. International Studies Review, 131(1), 122-132. https://doi.org/10.1111/j.14682486.2010.01003.x.

Fukuda-Parr, S., Greenstein, J., \& Stewart, D. (2013). How should MDG success and failure be judged: Faster progress or achieving the targets? World Development, 41, 19-30. https://doi.org/10.1016/j.worlddev.2012.06.014.

Fukuda-Parr, S., \& Hulme, D. (2011). International norm dynamics and 'the end of poverty': Understanding the Millennium Development Goals (MDGs). Global Governance, 17(1), 17-36.

Fukuyama, F. (2013). What is governance? Governance, 26(3), 347-368. https://doi. org/10.1111/gove.12035.

Grindle, M. S. (2004). Good enough governance: Poverty reduction and reform in developing countries. Governance, 17, 525-548. https://doi.org/10.1111/j.09521895.2004.00256.x.

Hailu, D., \& Tsukada, R. (2011). Achieving the Millennium Development Goals: A measure of progress. Working Paper 78, International Policy Centre for Inclusive Growth, Brasilia.

Harttgen, K., \& Klasen, S. (2013). Do fragile countries experience worse MDG progress? Journal of Development Studies, 49(1), 134-159. https://doi.org/ 10.1080/00220388.2012.713471.

Hobijn, B., \& Franses, P. H. (2001). Are living standards converging? Structural Change and Economic Dynamics, 12, 171-200. https://doi.org/10.1016/S0954349X(00)00034-5.

Hulme, D. (2015). Global poverty: Global governance and poor people in the post-2015 era. London: Routledge.

Hulme, D., Savoia, A., \& Sen, K. (2015). Governance as a global development goal? Setting, measuring and monitoring the Post-2015 Development Agenda. Global Policy, 6(2), 85-96. https://doi.org/10.1111/1758-5899.12181.

ICRG (2012). International country risk guide researchers dataset, table 3B, third edition [Data file]. East Syracuse, NY: The Political Risk Services Group.

Imai, K. S., Gaiha, R., \& Thapa, G. (2010). Is the Millennium Development Goal on poverty still achievable? The role of institutions, finance and openness. Oxford
Development Studies, 38(3), 309-337. https://doi.org/10.1080 13600818.2010 .505685 .

Kelley, J. G., \& Simmons, B. A. (2015). Politics by number: Indicators as social pressure in international relations. American Journal of Political Science, 59(1), 55-70. https://doi.org/10.1111/ajps.12119.

Kenny, C. (2005). Why are we worried about income? Nearly everything that matters is converging. World Development, 33(1), 1-19. https://doi.org/10.1016/ j.worlddev.2004.06.016.

Khan, A., Naveed, A., Samman, E., Sarwar, M. B., \& Hoy, C. (2015). Progress under scrutiny: Poverty reduction in Pakistan. ODI Research reports and studies. Retrieved from: https://www.odi.org/publications/9957-pakistan-extremepoverty-measuring-inequality-statistics.

Kwon, H.-J., \& Kim, E. (2014). Poverty reduction and good governance: Examining the rationale of the Millennium Development Goals. Development and Change, 45(2), 353-375. https://doi.org/10.1111/dech.12084.

Lomazzi, M., Borisch, B., \& Laaser, U. (2014). The Millennium Development Goals: Experiences, achievements and what's next. Global Health Action, 7(1). https:// doi.org/10.3402/gha.v7.23695.

Mahmud, W. Asadullah, M. N., \& Savoia, A. (2013). Bangladesh's achievements in social development indicators: Explaining the puzzle. Economic and Political Weekly, 48(44).

Marshall, M. G., Jaggers, K., \& Gurr, T. R. (2011). Polity IV Project: dataset users manual. Vienna, VA: Center for Systemic Peace.

McGee, R. (2000). Meeting the international poverty targets in Uganda: Halving poverty and achieving universal primary education. Development Policy Review. 18(1), 85-106.

Neumayer, E. (2003). Beyond income: Convergence in living standards, big time Structural Change and Economic Dynamics, 14, 275-296. https://doi.org/10.1016/ S0954-349X(02)00047-4.

Noorbakhsh, F. (2007). International convergence or higher inequality in human development? Evidence for 1975-2002. In G. Mavrotas \& A. F. Shorrocks (Eds.) Advancing development: Core themes in global economics (pp. 149-167). Basingstoke, UK: Palgrave Macmillan.

Ortega, B., Casquero, A., \& Sanjuán, J. (2016). Corruption and convergence in human development: Evidence from 69 countries during 1990-2012. Social Indicators Research, 127(2), 691-719. https://doi.org/10.1007/s11205-015-0968-8.

Prados de la Escosura, L. (2015). World human development: 1870-2007. Review of Income and Wealth, 61, 220-247. https://doi.org/10.1111/roiw.12104.

Pritchett, L. (1997). Divergence, big time. Journal of Economic Perspective, 11(3), 3-17. https://doi.org/10.1257/jep.11.3.3.

Quah, D. (1993). Galton's Fallacy and tests of the convergence hypothesis Scandinavian Journal of Economics, 95, 427-443. https://doi.org/10.2307/ 3440905.

Ravallion, M. (2012). Why don't we see poverty convergence? American Economic Review, 102(1), 504-523. https://doi.org/10.1257/aer.102.1.504.

Rodrik, D. (2013). Unconditional convergence in manufacturing. Quarterly Journal of Economics, 128(1), 165-204. https://doi.org/10.1093/qje/qjs047.

Sala-i-Martin, X. X. (1996). The classical approach to convergence analysis. The Economic Journal, 106(437), 1019-1036. https://doi.org/10.2307/2235375.

Savoia, A., \& Sen, K. (2015). Measurement, evolution, determinants and consequences of state capacity: A review of recent research. Journal of Economic Surveys, 29(3), 441-458. https://doi.org/10.1111/joes.12065.

Seyedsayamdost, E. (2017). Millennium Development Goals: Impact on national strategies and spending. Development Policy Review, 00, 1-30. https://doi.org/ $10.1111 /$ dpr.12314.

Sharma, P., Dwivedi, S., \& Singh, D. (2016). Global poverty, hunger, and malnutrition: A situational analysis. In U. Singh, C. Praharaj, S. Singh, \& N. Singh (Eds.), Biofortification of food crops. New Delhi: Springer.

Smith, L. C., \& Haddad, L. (2015). Reducing child undernutrition: Past drivers and priorities for the post-MDG era. World Development, 68, 180-204. https://doi. org/10.1016/j.worlddev.2014.11.014.

Sumner, A., \& Tiwari, M. (2009). After 2015: International development policy at a crossroads. London: Palgrave Macmillan.

Tebaldi, E., \& Mohan, R. (2010). Institutions and poverty. Journal of Development Studies, 46(6), 1047-1066. https://doi.org/10.1080/00220380903012730.

UNDESA (2015). The millennium development goals report 2015. New York: United Nations. Retrieved from: http://www.un.org/millenniumgoals/reports.shtml.

United Nations Millennium Project (2005). Investing in development: A practical plan to achieve the Millennium Development Goals (Main Report). New York: United Nations.

Waage, J., Banerji, R., Campbell, O., Chirwa, E., Collender, G., Dieltiens, V., et al (2010). The Millennium Development Goals: A cross-sectoral analysis and principles for goal setting after 2015. Lancet, 376(9745). https://doi.org/ 10.1016/S01406736(10)61196-8.

Williams, A. (2009). On the release of information by governments: Causes and consequences. Journal of Development Economics, 89, 124-138. https://doi.org/ 10.1016/j.jdeveco.2008.08.001.

World Bank (2014). Worldwide development indicators 2014 [Data file]. Retrieved from: https://openknowledge.worldbank.org/handle/10986/18237. Accessed in December 2014.

World Bank (2015). Worldwide development indicators 2015 [Data file] Retrieved from: http://data.worldbank.org/products/wdi. 